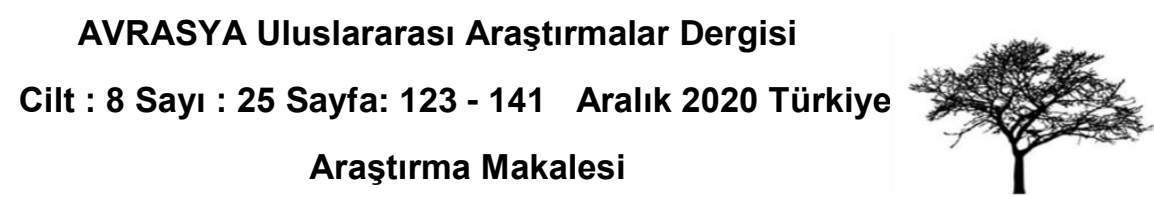

\title{
AYINTAB DARÜLEYTAMLARI
}

Dr. Öğr. Üye. Özlem MURAZ BUDAK*

Öz

XIX. yüzyılın ikinci yarısı ve XX. yüzyılın başı Osmanlı Devleti'nde gerek siyasi ve askeri gerekse sosyal-ekonomik anlamda büyük sıkıntıların yaşandığı, devleti çöküşe götüren dönem olmuştur. Avrupalı devletlerle yapılan savaşlar, devlet teşkilatında ve buna bağlı olarak sosyal yapılanmada derin yaralar açmıştır. Yapılan savaşlarda ölenlerin yanı sıra geriye kalan sakat, muhtaç ve yetimlerin sayısı gün geçtikçe artmıştır. Sosyal bir devlet olan Osmanlı, bu anlayışla intiyaç sahibi bu insanların himaye edilmesi, barındırıması noktasında kendinden önceki Türk devletlerinden devraldığı vakıf geleneğini sürdürmenin yanı sıra farklı çözüm arayışlarına girmiştir. Süreç içerisinde bu anlamda Eytam Sandıkları, Islahhane, Darülhayr-ı Âli, Darüşşafaka, Darülaceze gibi yeni kurumlar tesis edilmiştir. Bu kurumlardan biride Darüleytam yani Yetimler Evi'dir. Balkan Savaşı ve Birinci Dünya Savaşı sonrası ortada kalan yetimlerin iskân ve eğitimleri sorunu Darüleytamların kuruluş amacını oluşturmuştur. İlk olarak merkez İstanbul'da faaliyete başlayan kurum süreç içerisinde taşralarda da faaliyete geçmiştir. Darüleytamlar kurumsal olarak her ne kadar 1914 yılında faaliyete geçmiş ise de Ayıntab Kazasında bu tarihten çok daha öncesinde yetimler evi olduğu bilinmektedir. Ayıntab'da Müslümanlara ait yetimler evi dışında Ermenilere, İngiliz ve Amerikalılara ait yetim evleri bulunmaktaydı. Avrupalı devletlerin misyoner faaliyetleri çerçevesinde özellikle Amerikalılara ait birden fazla yetim evinin oluşundaki sebeplerin başında hiç kuşkusuz yüzyıllarca Ayıntab'da Müslümanlarla iç içe yaşamış olan Ermenilerin etkisi olduğu bir gerçektir.

Anahtar Kelime: Ayıntab, Darüleytam, Amerikalı Misyoner, Yetim, Ermeni

\section{ABSTRACT}

$X I X$. the second half of the century and XX. The beginning of the century was the period in which great political, military and social-economic problems were experienced in the Ottoman Empire, leading the state to collapse. The wars with European states have caused deep wounds in the state organization and, accordingly, in social structuring. In addition to those who died in the wars, the number of the remaining disabled, needy and orphans has increased day by day. With this understanding, the Ottoman Empire, as a social state, sought different solutions as well as maintaining the tradition of foundation that it inherited from the previous Turkish states in terms of protecting and hosting these people in need. In the process, new institutions such as Orphans' house Funds, Islahhane, Dârülhayr-ı Âlî, Dârüşşafaka, Darülaceze were established. One of these institutions is Darüleytam, the Orphans House. The problem of the settlement and education of orphans after the Balkan War and the First World War was the foundation purpose of Darüleytams. The institution, which first started its activities in central Istanbul, has also been active in the provinces in the process. Although Darüleytamlar institutionally started its operations in 1914, there were orphans' houses in Ayıntab district long before this date. In Ayıntab, apart from the orphans' houses belonging to the Muslims, there were more than one orphanage belonging to the Armenians, British and American missionaries. It is a fact that the main reason behind the existence of more than one orphan house belonging to Americans within the framework of the missionary activities of European states is undoubtedly the influence of Armenians who lived together with Muslims in Ayıntab for centuries.

\footnotetext{
* Gaziantep Üniversitesi, Nizip Eğitim Fakültesi, Türkçe Ve Sosyal Bilimler Eğitimi Bölümü, Sosyal Bilgiler Eğitimi Anabilim Dalı, ozlem-muraz@hotmail.com OrcId ID: 0000-0001-2345-6789
} 
Keywords: Ayıntab, Darüleytam, American Missionary, Orphan, Armenian

\section{Giriş}

Sözlükte, babası ya da hem babası hem anası ölmüş çocuk anlamına gelen yetim kelimesi, herhangi bir şeyin tekil halini ifade etmek için kullanıldığı gibi korunmayan inmal edilen kişi anlamında da kullanılmaktadır. Terim olarak yetim(çoğulu eytam), büluğa ermeden babasını kaybeden çocuklar için ifade edilmektedir. Türkçede babasını kaybeden çocuklar için yetim; annesini kaybeden çocuklar için ise öksüz kelimesi kullanılmaktadır(Sami 1317:1544; Dönmez 1986:401-403; Dikici 2019:16; Kanar:519). İslam dini yetimlere büyük önem vermektedir. Yetimlerin korunup kollanması yönünde Kur'an-ı Kerim'de birçok ayet olduğu gibi kendisi de yetim olan $\mathrm{Hz}$. Peygamberin konuyla ilgili birçok hadisi vardır(Bakara/83,177, 215, 220; Nisa/2, 3, 6, 8, 10, 36, 127; En'am/153, İsrâ/ 34; Kehf/82; Fecr/17; Naziri 2019:36).

Osmanlı, birçok konuda olduğu gibi sosyal devlet anlayışı temelini de kendisinden önce kurulan Türk-İslam Devletleri'nden almıştır. Bu anlamda Osmanlı Devleti, başta öksüz ve yetimler olmak üzere intiyaç sahibi insanlara bu Türk-i̇slam medeniyetlerinde var olan vakıf geleneğini geliştirerek ve yeni sosyal kurumlar faaliyete geçirerek sahip çıkmıştır(Doğan 2014:444). Eski Türklerde gelenek ve göreneklere dayanan sosyal hizmet ve yardım anlayışı, İslamiyet'in kabulüyle birlikte sosyal bünyede kökleşmiş ve vakıflar vasıtasıyla toplum intiyaçlarının karşılanması için çalışmıştır. Kişinin sahip olduğu maddi mal varlığının tamamını ya da bir kısmını Allah rızası için dini ve hayrî olarak toplumsal bir amaç için tahsis etmesi malını vakfettiği anlamına gelmektedir. (Yediyıldız 1999:17). Bu anlamda vakıflar ihtiyaç sahibi çocukların korunması, eğitilmesi ve topluma kazandırılması anlamında da çalışmalar yapar ve bütçe ayırırlardı(Ateş 1982:55).

Osmanlı Devleti hukuki olarak da yetimlerini güvence altına almakta idi. Tereke, ölen bir kimsenin miras olarak bıraktığı her türlü mal veya eşyanın tümünü ifade etmektedir. İslam hukuku çerçevesinde öncelikle ölen kişinin cenaze masrafları karşılanıp borçları ödendikten sonra terekenin mirasçılar arasında paylaşımı yapılırdı. Vasilik ailede babanın ölümü ya da ehliyetsiz bulunduğu yani çocuklarının hak ve hukuklarını koruyacak akli dengesi olmadığı hallerde başvurulan bir durumdur. Kadıların görevleri arasında da veli veya vasisi olmayan küçükleri evlendirme; yetimlerin ve gaiplerin mallarını muhafaza; vasi ve vekilleri tayin yahut azillerini yer almaktadır(Çanlı 2002:57). Baba ölmeden önce çocuklarına vasiyet yoluyla vasi tayin edebilmekte idi. Ancak aksi durumunda mahalli mahkeme kadısı ya da naibi tarafından Müslim-gayrimüslim yetim ayırt etmeksizin vasi tayini yapılırdı. Vasi atanan kişiler, herhangi bir ücret almazdı(Çanlı 2002:58-60; İnanç 2002:15). Yetime vasi tayin edilen kişi yetimin annesi, babası, ninesi, dedesi, amcası, dayısı veya kayınpederi olduğu gibi çocukla hiçbir akrabalık bağı bulunmayan birinin de vasisi olabildiği görülmektedir (Ayıntab Şer'iyye SiciliNo.144:115,178,188;145:9,10,12,14,18,21,30,32,47,48,52,55,57,58,59,83,91,109, 122;147:8,154,190,247).

Tereke usulü konusunda, kadı ve diğer görevli memurlar hakkında zamanla artan şikâyetler 1851 yılında öncelikle İstanbul'da bir Emval-i Eytam Nezareti ve buna 
bağlı Eytam Sandığı๋ ve meclislerin kurulmasını zorunlu kılmıştır. Eytam Nezaretinin kurulmasındaki temel düşünce ise yetimlere miras kalan malların gerek kadı gerekse vasi tarafından zayi edilmeden kaydedilmesi ve çocuk rüşt yaşına gelene kadar güvenli şekilde mallarının işletilerek faiziyle kendisine verilmesiydi(Şahin 2017:50). Birinci Dünya Savaşı sonrası daha da bozulan ekonomik sebeplerden dolayı zarar gören Eytam idaresi ve sandıkları 1920 tarihinde önce merkez İstanbul'da; 1926 yılında ise taşralarda kaldırımıştır(İnanç 2002:57). Bu uygulamalardan da anlaşılmaktadır ki devlet her şekilde her dönem ve koşulda yetimlerine ve intiyaç sahiplerine sahip çıkmış, onları gözetmiştir.

XIX. yüzyıl ve XX. yüzyılın ilk çeyreği Osmanlı Devleti'nde hem askeri ve siyasi hem de sosyo-ekonomik anlamda büyük sıkıntıların yaşandığı devleti çöküşe götüren bir dönem olmuştur. Avrupa devletleriyle yapılan savaşlar Osmanlıya karşı yapılan isyanlar devlet teşkilatını ve buna bağlı olarak sosyal yapılanmayı büyük sıkıntılara düşürmüştür. Savaşlar sonucunda ölenlerin yanı sıra sakat, muhtaç ve yetimlerin sayısı oldukça artmıştır. Bir sosyal devlet olan Osmanlı, bu anlayışla intiyaç sahibi bu insanların barındırılması noktasında çözüm arayışlarına girmiştir. Tanzimat'ın ilanını takip eden süreçte, sorun yaşanan birçok alanda yeni düzenlemeler yapılmış ve yeni kurumlar tesis edilmiştir(Doğan 2014:444).

Tanzimat döneminde Rumeli valisi Mithat Paşa tarafından öksüz ve yetim çocukların korunup eğitim alması amacıyla 1863 yılında Niş'de, 1864 yılında Rusçuk ve Sofya'da Islahhane ismiyle Müslim ve gayrimüslim çocuklar için okullar açılmıştır. Ayrıca sadece kızlar için 1865 yılında Rusçuk'ta bir ıslahhane açılmış, devamında İstanbul başta olmak üzere birçok şehirde de ıslahhaneler faaliyete girmiştir(Yazıcı 1995:48; Akyüz 1999:12-32).

Islahhanelere din farkı gözetilmeden on üç yaşından küçük, annesi babası olmayan ya da anne veya babasından biri hayatta olan fakir çocuklar kabul edilmekteydi. Öğrenci ilk hafta çeşitli denemelerden geçirilir ve yeteneklerine göre bir mesleğe yönlendirilirdi. Öğrenciler bir yandan meslek öğrenirken bir yandan da ordunun ayakkabı ve giyim intiyaçlarını temin etmekteydiler. Bu şekilde teşekkül eden döner sermaye ile kurumun kendi giderleri karşılanmaktaydı. Bu döner sermaye geliri dışında geliri kuruma aktarılmış vakıf gelirlerinin olduğu da anlaşılmaktadır. Islahhaneler II. Abdülhamid döneminde sanayi mektebi haline getirilmeye başlanmış, ayrıca İstanbul'da yetimler için ıslahhane tarzında bir Darülhayr-ı Âli kurulmuştur(Öztürk 1999:190,191).

Osmanlı Döneminde öksüz ve yetimlerin eğitimi ve himayesi için açılan bir diğer kurum, ilk kuruluş adı Darüşşafakatü'l- İslâmiyye olan ve şefkat yurdu anlamına gelen Darüşşafaka'dır. Bu eğitim yuvası, 1873 yılında Yusuf Ziya Paşa, Sadrazam Gazi Ahmed Muhtar Paşa, Sadrazam Esad Paşa, Vidinli Tevfik Paşa, Ali Naki Efendi ve Sadrazam Sakızlı Ahmed Esad Paşa tarafından kurulan Cem'iyyet-i Tedrîsiyye-i İslâmiyye Cemiyeti öncüğünde maddi durumu iyi olmayan öksüz ve yetim Müslüman

\footnotetext{
* Halep Vilayeti salnamesinden edindiğimiz bilgilere göre Ayıntab Kazasında ilk kez 1290(1873/74) tarihli salnamede Eytam Sandığı ifadesi geçmekte ve Eytam sandığı memurunun Osman Efendi olduğu ve sandık sermayesinin 84.315,15 olduğu yer almaktadır(Salnâme-i Vilâyet-i Haleb Sene 1290:59).
} 
çocukların eğitimi için açılmıştır. Kurum zaman içerisinde çeşitli değişimler geçirse de varlığını günümüzde de devam ettirmektedir(Ayhan-Maviş 1994:7-9; Koç 2003:183,184).

Darülaceze, II.Abdülhamid döneminde bilhassa dilencilikle mücadele amacıyla dilenen kimsesiz çocuklara, sakat kadın yada erkeklere din farkı gözetmeksizin barınma ve eğitim imkanı sağlamak amacıyla 1896 yılında hizmete açılmıştır. Bu kurum, günümüzde halen varlığını sürdürmektedir(Nuhoğlu 1993a:512-514).

Darülhayr-ı Âli'nin kurulmasında o dönemin siyasî ve sosyal olayları etkili olmuştur. Nitekim bir taraftan 1877-78 Osmanlı-Rus Savaşı diğer taraftan savaş sonrası birçok yerde çıkan isyanların etkili olduğu görülmektedir. Bu olayların sonucunda Anadolu'nun da birçok yerinde Ermeni isyanları baş göstermiştir. Sonuç olarak Müslim-gayrimüslim ortada kalan öksüz-yetim çocuklar ve dullar sorunu ortaya çıkmıştır. Osmanlı Devleti yaşanan bu sorunlara çözüm amacıyla hem Müslüman çocukları koruma altına almak hem de Ermeni çocukları üzerinde misyoner faaliyetleri engellemek için harekete geçmiştir. Daha önce bu amaçla kurulan ıslahhanelerde amacına ulaşamamıştır. Önceleri Müslim-gayrimüslim halkı kapsayacak bir yetimhane kurulması düşünülmüşse de ekonomik imkânsızlıklar nedeniyle vazgeçilerek Müslüman çocukların eğitimi ve korunmasına yönelik bir kuruma karar verilmiştir. Bu kurum, 1903 tarihinde İstanbul'da açılmış ve 2. Abdülhamid himayesinde olması bakımından Darülhayr-i Âli ismini almıştır(Kapcı 2012:50,51,60; Karataş 2015:23-24).

Yukarıda vermiş olduğumuz bilgilerden de anlaşıldığı üzere çalışma konumuz Darüleytamların kuruluşuna kadar olan süreçte genel anlamda Osmanlı Devleti'nin yardıma muhtaç çocuk ve kişiler için yaptığı çalışmalar ve bu anlamda meydana gelen kuruluşlara yer vermeye çalıştık. Aşağıda darüleytamlar hakkında kısaca bilgi vererek Ayıntab Kazasında bulunan darüleytamlar ele alınacaktır.

\section{Darüleytamlar}

Arapça ev anlamına gelen "dâr" ve yetimler anlamına gelen "eytam" kelimelerinin birleşmesiyle oluşan darüleytam; yetim evi, yetimhane anlamına gelmektedir(Pakalın 1993:393,578). Osmanlı Devleti'nin son dönemlerinde yaşanan siyasi ve askeri gelişmeler sonucunda art arda yapılan savaşlar toplum yaşamında ekonomik ve sosyal anlamda sıkıntılara sebebiyet vermiş, bu durumda yetim sayısının önemli ölçüde artmasına neden olmuştur. Gerek 1877-78 Osmanlı-Rus Savaşı gerekse Balkan Savaşı'nda Anadolu'ya yapılan göçler ve neticesinde geriye kalan yetimler Darüşşafaka, Darülaceze gibi kurumlara yerleştirilmişlerdir. Balkan Savaşı sonrasında da İstanbul'a yüzlerce yetim gelmeye devam etmiş Darülacezeler yetersiz kaldığı için yatılı sultanilerde barındırılmışlardır. Ancak I. Dünya Savaşı sebebiyle yetim kalan çocukların birçoğu sultanilerde de yer olmadığından hayatlarını kaybetmişlerdir(Okur 1996:19).

Darüleytam, yaşanan bu sıkıntılara çözüm bulmak adına dönemin Maarif Nâzırı Ahmed Şükrü Bey'in öncülüğünde 25 Kasım 1914 tarihinde kurulmuş ve 1915 başlarında İttihat ve Terakki Fırkasına bağlı olarak faaliyete geçmiştir. Kurumun asıl kuruluş hikâyesi 1899 yılına dayandırılmaktadır. 5 Temmuz 1899 tarihinde Maarif 
Nezareti tarafından bir darüleytam talimatnamesi hazırlanmış ise de darüleytamların açılması 1914 yılını bulmuştur(Şafak 2013:263).

Kurumun ilk müdürü İttihatçıların İstanbul merkez başkanı Kemal Bey, ilk genel müdürü ise Kastamonu Milletvekili İsmail Mahir Efendi olmuştur. Darüleytamlar, din farkı gözetmeksizin daha önce misyoner(Fransız, İngiliz vs.) okullarında kalan ancak misyonerlerin ülkeyi terk etmeleriyle kimsesiz kalan çocuklara da kucak açmıştır. Aynı zamanda boşalan okul ve binaları darüleytama dönüştürülmüştür. Darüleytamlar, yetimleri himaye etmenin yanı sıra mesleki eğitimlerde vererek iş sahibi olmalarını ve geleceklerini güvence altına almaları amaçlamıştır(Nuhoğlu 1993b:521; Özkan 2006:216).

Darüleytam 1914 yılı son günü leyli yani yatılı olarak İstanbul'da faaliyete girmiştir. 1916 itibariyle Darüleytam ana kucağı yani (kreş) 2-3 yaş kız ve erkek çocuklar; anaokulu 4-6 yaş kız ve erkek çocuklar; ilkokul 7 yaşından büyük kız çocuklar ve kız sanat okulu olmak üzere dört şube olarak faaliyete girmiştir. Anaokulunun mevcudu 200 idi. 6 yaşını dolduran öğrenciler parasız olarak sultanilere kaydedilecekti. İlkokul süresi 6 yıldı. Kız sanat okulu öğretim süresi 3 yıl olup 100 öğrenci kabul edilmesi planlanmıştı(Müezzinoğlu 2012:401,402).

Devlet, darüleytamlara öncelikli yerleşecekleri belirlemek adına kararnameler yayınlamıştır. Buna göre birinci derecede savaşta şehit düşen ya da sakat kalan asker çocukları ile mülteci-muhacir maaşından mahrum olanların çocuklarının barınması kararlaştırıldı. İkinci dereceden ise kimsesiz yetimlerin kabulü kararlaştırıldı. Darüleytamlara önce yaklaşık 10.000 şehit çocuğu yerleştirilmiş ama zamanla hazine maddi sıkıntıya girince kurumun azaltılması zorunluluğu ortaya çıkmıştır. Yakın akrabası olan yetimler oralara yerleştirilmiş, bir kısmı ise evlatlık verilmek suretiyle hazine rahatlatılmaya çalışılmıştır(Okur 1996:20,21).

Darüleytamlar ilk kuruldukları (1914) dönemde İstanbul merkez ve taşralarda toplam sayısı 20 idi. Süreç içerisinde yetim sayısının artmasıyla Darüleytamların sayısı da artmış sonradan kapatılmak zorunda kalınanlarla birlikte ülke genelinde 80'i bulmuştu(Ergin 1977:1551). 1916 yılında kurumda barınan yetim sayısı kız 5000, erkek 15000 olmak üzere 20000 idi(I̧şeri 2014:70). Diğer yandan 1918'e gelindiğinde Darüleytam teşkilatının bir nizamname veyahut talimatnamesi olmamasına bağlı olarak alınan kararlara uyulmayarak darüleytamlara 17-22 yaş aralığında hatta babası olan çocukların asker kaçaklarının vs. alındığı tespit edilmiştir(Okur 1996:22).

\section{Darüleytam İdaresi ve Bütçesi}

Darüleytamlar ilk kurulduklarında (Maarif Nezareti işi olarak görülmeyerek) İttihat ve Terakki Fırkası önderliğinde, İstanbul merkez idaresinden Kemal Bey ve Kastamonu Mebusu İsmail Mahir Efendi genel müdürlüğünde idare edilmiştir. İlk zamanlar darüleytamların yerleştikleri binalar arasında mektep, manastır gibi yerler olduğu için bu binaların depolarında bulunan eğitim malzemeler, levazım ve gıda maddelerinden faydalanılmıştır. Ancak zamanla savaş durumunun uzamasıyla el konulan malzemelerin bitmesi ve mali sıkıntıyla beraber hükümetçe kurum idaresi önce Maarif Nezaretine bağlanmış daha sonra ise özel bir bütçeyle Darüleytam Genel Müdürlüğüne bırakılmıştır(Özkan 2006:217). 
Darüleytamlara yeni gelir kaynakları sağlamak adına 16 Mayıs 1914 tarihinde neşredilen kanun 2 Nisan 1916 tarihinde kabul edilmiştir. Buna göre devlet tarafından, her yıl özel idare ve belediye bütçelerinden yardım yapılacaktı. Ayrıca maliye tarafından bir kereye mahsus olmak üzere 150 bin lira nakit ve 500 bin dönüm arazi verilmesi uygun görülmüştür. Ancak daha sonra bu gelirlere ek olarak 3 Nisan 1916 yılında yeni bir kanunla posta-telgraf, tütün-içki fiyatları vergilerine ek olarak arttırımıştır. Kurum içerisinde ayrıca uygulamalı eğitim verilebilmesi ve gelir getirmesi hasebiyle ziraat ve sanayi şubeleri açılmıştır. Kurum intiyaçları giderildikten sonra üretim fazlası satılmakta idi. Aynı zamanda kuruma tahsis edilen kira gelirleri, hayırseverlerin yaptıkları bağışlar vs. darüleytamların diğer gelirleri arasındadır(Ergin 1977:1549; Okur 1996:30).

Mondros Mütarekesi sonrası İstanbul'un yeniden işgaliyle beraber işgal orduları, darüleytamların yerleştikleri okullarının boşaltılmasını istediler. Bu okullarda barınan ve sayısı 5000'i bulan yetimler bizzat dönemin padişahı VI. Mehmet Vahdeddin talimatıyla uygun olan bazı saray, köşklere yerleştirilmişlerdir. Zaman içerisinde bu olayda olduğu gibi çeşitli nedenlerle ya da imkânsızlıklarla sıklıkla yer değişiklikleri olmuştur(Aytekin 2006:61).

I. Dünya Savaşı yenilgisinin ekonomik sonuçları diğer yandan Mondros Mütarekesi'nin sebep olduğu kaos ortamı neticesinde darüleytam bütçelerinde kısıtlamalara gidilmiştir. Bir süre sonra hükümetin darüleytamlara bütçe sağlayamayacağının anlaşılmasıyla taşralarda bu kurumların kapatılmasına ve buradaki yetimlerin İstanbul'da toplanmasına karar verildi(1918). Bu öğrenciler İstanbul'da şehir yatı mektebi ismiyle özel idareye verildiyse de sonrasında tamamen kapatıldılar. İçlerinden yetenekli olanlar ise Dârüşşafaka'ya kaydedilmişlerdir(1927)(Nuhoğlu 1993b:521; Müezzinoğlu 2012:416; Karataş 2015:27).

\section{Ayıntab Darüleytamları}

\section{Müslümanlara ait olan Darüleytamlar}

Osmanlı Devleti'nde darüleytamların kurumsal olarak açılması her ne kadar 1914 tarihinde olsa da çok öncesinde Ayıntab Kazasında yetimhaneler ve okulları mevcuttu. Ayıntab'da 1881 yılında bir yetim okulu vardı(Enç 1962:5; Gögüş t.y: 282; Yıldıray 2010:84; Güllü 2010:96). Araştırmacı yazar Yener'e göre bu okul Eskisaray civarında bulunan Şıra dükkânlarının üstünde bulunan tek kat salonda bir sınıf ve bir öğretmen ile faaliyet göstermekteydi. Sadece okuma-yazma öğretilen bu mektepte, diğer mahalle mekteplerinde hocaya haftalık olarak ödenen hamislik ücreti ödenmiyordu. Üç yıl ve gündüz olarak eğitim alan bu çocuklar akşamları kendi evlerine, evleri yok ise kendilerine bakmayı kabul eden ailelerin yanlarına giderlerdi. Bu Eytam Mektebi'nin H.1321 (M.1903-1904) tarihinde Mahmudiye Mektebi'nin açılmasıyla ortadan kalktığı ifade edilmektedir(Yener t.y.:7,8; Yıldıray 2010:86). Halep Vilayet Salnamelerinin Ayıntab kısmında ilk kez H.1302(M.1884-85) tarihinde yetimhane ifadesi kullanılmıştır H.1308 (M.1890-1891) tarihli salname itibariyle ise Eytam Mektebi olarak geçmektedir(Salnâme-i Vilâyet-i Haleb 1302:165; 1308:165; Yıldıray 2010:159,169). Diğer bir kaynakta ise okulun adı iptidai mektebi olarak geçmektedir. Buna göre Ayıntab Belediyesinin 1886 yılı masraf kayıtlarında Eytam İptidai Mektebi hocası Vaiz İbrahim Efendi'nin aylık maaşının 100 krş. olduğu kaydedilmiştir. 1895 yılı 
bütçesinden 20 krş. 10 para Eytam Mektebi imtihan masrafı olarak ayrılmıştır. 1896 bütçesinde ise Eytam Mektebi muallimleri için $2280 \mathrm{krş.} \mathrm{maaş} \mathrm{ayrılmış} \mathrm{mektebin} \mathrm{yakıt}$ giderleri 325 krş. kaydedilmiştir(Barlas 1960:15,22; Yıldıray 2010:86).

Ayıntab yetimleri hakkında 1911 yılına ait bir arşiv belgesine kadar bir bilgi bulunmamaktadır. Nüfusunun büyük çoğunluğu Müslüman olan Ayıntab halkı kendi yetimlerine ve ihtiyaç sahiplerine sahip çıkacak yeterli yetimhane olmamasını üzüntüyle karşılamış ve harekete geçmiştir. Bu amaçla 1911 tarihinde yoksul ve çaresiz yetimlerin her türlü intiyaçlarının karşılanması ve eğitimleri için şehirde Ayıntab Himâye-i Eytam Cem'iyyet-i İslâmiyesi(Müslüman Yetimlerini Koruma Cemiyeti) unvanıyla bir cemiyet kurulduğu anlaşılmaktadır. 1914 tarihinde ise cemiyetin tüzüğü hazırlanarak amaçları belirtilmiştir. Buna göre cemiyetin amacı insanı derinden yaralayan kimsesiz, evsiz, işsiz öksüzlerin geçimlerini temin, eğitim almalarını sağlama ve bunların topluma kazandırımasına yardımcı olmaktır. Başlangıç olarak hayırseverlerin yardımlarıyla Ayıntab'ın çarşı ve mahallelerinde bulunan yetimlerin intiyaçlarını karşılamak amaçlanmıştır(BOA. DH. ID, 126/20; DH. EUM. EMN, 103/22). $\mathrm{Bu}$ cemiyet hakkında daha fazla bilgi bulunmamaktadır. Bu nedenle bu cemiyetin kuruluş amacını ne kadar gerçekleştirdiği bilinmemektedir.

1916-17 yılı itibariyle Ayıntab darüleytamları ile alakalı arşiv belgelerine rastlamaktayız. Ayıntab darüleytamında görev yapan muallimlerden Receb Efendi hakkında ilginç bir mesele yer almaktadır. Receb Efendi'nin 3 Ocak 1917 tarihinde darüleytamda girdiği din dersinde "Gururlu bir papas sizin Muhammedinizden, İsa ve Musa'dan vesair peygamberlerden iyidir. Arapça hutbe ve ezanlardan Kur'an'dan bir şey anlamıyoruz. Yalnız Arapların karınlarını doyurmak için Hicaz'a gidenler arkalarında ailelerini çocuklarını sefil bırakıyorlar. Oruç tutan adam cinnet getirir. Sonra ölür. Cahil ahali ise bunların kabrini ulemadandır diye ziyaret ediyorlar. Yat, kalk diye namaz kılmaktan bir şey çıkmaz. Din kitaplarından da bir şey anlaşılmaz. Bunlar da saçmadır" gibi sözler sarf ederek çocukların zihinlerini bulandırdığı ve bunu bir misyonerden daha tehlikeli olan ve Müslüman görünümünde yaptığı dile getirilerek müftü, müderris vesairenin şikâyeti ve Recep Efendi'nin görevden el çektirilmesi talebi ile 3 Mart 1917 tarihinde ise müftü, müderris vesairenin çektikleri telgrafın değerlendirildiği ve soruşturma açıldığı ifade edilmektir. Ayrıca Recep Efendi'nin işin nereye varacağını gördüğü için istifa ederek ortadan kaybolmasının halkın heyecana gelmesine ve asayişin bozulmasına sebep olabileceği için böyle bir hale sebep olma intimaline karşı ceza kanununun ilgili maddeleri gereği yargılanması için savcılığa havale edildiği ve böylece hakkında açılan idari tahkikatın adli tahkikata dönüştüğü bilgisi yer almaktadır. Recep Efendi kendisinden talep edilen kefaleti ödemediği gibi Müslüman halkın galeyana gelerek asayişin bozulacağı endişesi ile tutuklu yargılanmasının uygun olacağına karar verilmiştir(DH. HMŞ, 3-1/8-2; DH. I. UM. EK, 28/104).

Ülke genelinde yukarıda bahsettiğimiz üzere savaşların sebebiyet verdiği özellikle ekonomik sıkıntılar darüleytamların işleyişini ve de gelirlerini de olumsuz etkilemiştir. Ayıntab İlköğretim Müfettişliğinden gönderilen 1 Nisan 1917 tarihli yazıda Ayıntab Kazasında görevli muallimlerin maaşlarının askıda kaldığı ve ödeme emrinin 
gelmemesinden dolayı kendilerinin zor durumda oldukları söz konusu ödeme emrinin birikmiş maaşlarıyla birlikte yapılması hususunun muhasebe müdürlüğüne bildirilmesi üzerine Maarif Nezaretince Ayıntab darüleytamı için yardım olarak maaş ve masraf karşılığı için vilayet bütçesine 42200 kuruş ilave edildiği belirtilmektedir(MF. MKT, 1225/21). Yine Kilis ve Ayıntab darüleytamlarında yapılan genel kontrolde mahalli idarenin yardımı ile yemek giderlerinin karşılandığı ve bu yüzden pek çok sıkıntı yaşandığı anlaşılmış, buğday, bulgur, yağ gibi gıda maddelerinin mevsiminde tatil dönemi olan haziran, temmuz ve ağustos aylarında temin edilerek hazır bulundurulması satın alınarak depolanması gerektiği talimatı verilmiştir(7 Haziran sene 1333/1917)(MF. MKT, 1227/16; MF. MKT, 1227/45).

Ayıntab Mutasarrıflığından, Ayıntab Darüleytam Müdürlüğüne gönderilen Maarif Nezaretinin telgrafında 1917 mali yılının başından itibaren darüleytam iaşesinin ne şekilde karşılandığının sorusuna Darüleytam Müdürlüğü tarafından verilen cevapta mali yılbaşından (Mart ayı başından) itibaren hiç bir para alamadıklarını, ısrarlı talepler sonucu 6350 lira gibi günün şartlarında yetersiz bir paranın serbest bırakıldığı, ayrıca mahalli masraf sandığı encümeni tarafından da avans olarak 4000 kuruş verildiği, şahsa ait paralarla durumun idare edildiği (burada fedakârlık yaparak masrafları o güne kadar ceplerinden karşıladıkları ifade ediliyor) belirtilmiştir. 5 Mayıs 1917 tarihinde de maaşlara karşılık olarak ziraat bankası şubesinden alınmak üzere 18.729 krş. gönderildiği, ayrıca 29 Mayıs 1917 tarihinde ise $23.829 \mathrm{krş.un} \mathrm{da} \mathrm{maaş} \mathrm{ve} \mathrm{masraflar}$ için gönderildiği belirtilerek bu paralarla günün kurtarılmaya çalışıldığı ifade edilmektedir. Erzaklarında müteahhitlerden taahhüt suretiyle alınmaya çalışıldığı bu süre boyunca da müteahhitlerin askerlikten muaf tutulmaları için çalıştıkları bildirilmiştir. Kilis içinde durumun aynı olduğu Kilis kaymakamı tarafından Halep Maarif Müdürlüğüne yazılan yazıdan anlaşılmaktadır. Darüleytam Genel Müdürlüğü tarafından ziraat bankası vasıtası ile gönderilen paradan başka ayrıca mahalli imkânlarla da yardım yapıldığı ifade edilmektedir(MF. MKT, 1227/31).

Diğer yandan ülkede süregelen ekonomik sıkıntılar bir yana eğitimin en iyi şekilde devam edilebilmesi için devlet imkânlarını sonuna kadar sunmakta idi. 1916 yılı sonu Enver Paşa'nın da katkılarıyla Türk-Alman Dostluk Cemiyeti desteğiyle toplam 490 darüleytam öğrencisinin Almanya'ya gönderilmesi uygun görülmüştü(Çetinkaya 2009:85). Almanya'ya gönderilen talebelerin tüm masrafları Darüleytamlar Genel Müdürlüğünce karşılanmakta idi. Nitekim Maarif Nezaretinin emri ile Ayıntab ve Kilis darüleytamlarından Almanya'ya gönderilecek 25 talebenin müracaatları ile sultaniye eğitimine aday olmaları, bunların şahsi masrafları için ayrılan yirmi yedi bin kuruşun verilmesi ve avans olarak ödeme yapılması için Maarif Nezaretine müracaat edilmiştir(Mayıs 1917)(MF. MKT, 1226/20). Yine Ayıntab darüleytamı talebelerinden Mehmed ve Mustafa Efendilerin eğitim için Almanya'ya gönderilmeleri ve yol giderlerinin karşılanması için İstanbul'daki Darüleytamlar Genel Müdürlüğünce karşılanması talep edilmiştir(Haziran 1917)(MF. MKT, 1227/67). Almanya'ya örgün eğitim alma hayaliyle giden yetimlere sanayi, ziraat ve maden çıraklığı yaptırılmıştır. Başarı gösteremeyenler İstanbul'a dönmüşlerdir. Dönmeyenler ise orada yoksul bir yaşam sürmüş bir kısmı ölmüş hayatta kalanlar ise savaşın yenilgiyle sonuçlanması sonrası geri dönmüşler ve geçici olarak Darülaceze'ye yerleştirilmişlerdir(Çetinkaya 2009:85). 
1917 mali yılı mart ayına ait Maarif Nezaretinden gönderilen ödeme emrinde Ayıntab ve Kilis darüleytamları için 22868 kuruş ayrılmıştır. Ayrıca Almanya'ya eğitim için gönderilen talebeler için toplam $44028 \mathrm{krş.} \mathrm{gönderilmiş,} \mathrm{Kilis} \mathrm{ve} \mathrm{Ayıntab}$ darüleytamları talebesinden 25 talebenin her biri için 1000, öğrencilere refakat edecek öğretmenler için de 2000 krş. hesabıyla toplam 27000 krş. ödenmesi uygun görülmüştü. İstanbul'daki Darüleytamlar Genel Müdürlüğüne bu meblağlar için de ayrıca bir ödeme emri çıkarılması talep edilmiştir(Haziran 1917)(MF. MKT, 1227/69). Darüleytamlar Genel Müdürlüğünden ziraat bankası vasıtasıyla Ayıntab darüleytamına 33.829 krş ve Kilis darüleytamına 32.595 krş gönderilmiştir(Temmuz 1917)(MF. MKT, 1227/99).

İstanbul Genel Müdürlüğünce belirli zamanlarda taşra darüleytamlarından kurumların mevcut durumları hakkında bilgi istenirdi. Nitekim 26 Za 1334(24 Eylül 1916) tarihinde merkez ve taşra darüleytamlarında öğrenci, memur ve hizmetli mevcudunu gösteren bir cetvelde Ayıntab zükûr darüleytamında 100 erkek ve kız öğrenci, 3 kadın ve erkek öğretmen, 7 kadın ve erkek memur, 13 erkek-bayan hizmetli olmak üzere toplam 123 kişinin mevcut olduğu kaydedilmiştir(MF-EYT, 3/81; Aytekin 2006;71). Nisan 1917 tarihinde ise Ayıntab'da darüleytam sayısı 2, öğrenci sayısı 200, memur ve hizmetli sayısı 25 olmak üzere toplam 225 kişi mevcudu verilmektedir. Temmuz 1917 tarihli başka bir çizelgede ise Ayıntab erkek darüleytamı 13 hizmetli, 10 memur ve öğretmen olmak üzere toplam 23 kişi olarak kaydedilmiştir(MF.MKT., 1227/20; MF. EYT. 7/53; Müezzinoğlu 2012:405,406).

Darüleytamların İstanbul'daki genel müdürlüğe bağlanması hakkında Maarif Nezaretinden valiliklere yazı gönderilmiştir(3 Nisan 1917). Ayıntab ve Kilis darüleytamlarının İstanbul'daki genel müdürlüğe bağlandıkları hakkındaki emir gereği bu Darüleytam Müdürlüklerinin her husus için doğrudan genel müdürlüğe müracaat etmeleri gerektiği ve buralarda kalan eytamın korunup kollanması için yeni alınacak eytam için nezarete bilgi verilmesi hususunun önemi belirtilmiştir(MF. MKT, 1225/21; MF. MKT, 1226/104).

17 Ekim 1918(Teşrîn-i evvel 1334) tarihli Maarif-i Umûmiye Nezâreti tarafından Harbiye Nezaretine yazılan bir belgede Maraş ve Ayıntab darüleytamından Dersaadet darüleytamına nakillerine karar verilen 120 talebenin on günden beri Fatıma İstasyonu'nda son derecede perişan bir halde kaldıkları ve Kilis darüleytamının 40 talebesi de bunlara katılmak üzere bulunduklarından bu çaresiz yetimlerin sokaklarda ve ötede beride sefil ve perişan bir halde kalmayarak bir an evvel sevkleri için icap eden vagonların tahsis edilmesi talebinde bulunulmuştur(MF. MKT, 1236/45). Bir yıl sonra ise İstanbul'a nakil ettirilmiş olan Ayıntab mülgâ darüleytam talebelerinden 9 kişinin Dersaadetten firar ederek Ayıntab'a geldikleri belirtilerek devlet olarak bu gençlerin millete faydalı birer birey olarak yetiştirmek amacıyla dört yıl boyunca yedirmiş, giydirmiş ve okutmuştur. Bu gençlerin serseriyane, sefilane bir şekilde ortalıkta gezmelerinin esas itibarıyla takip edilen amaca ile kesinlikle bağdaşmadığı için gerekenin yapılması talep edilmiştir. Cevaben ise İstanbul'da kurumun Ayıntab'a firar eden bu gençleri yakalayıp tutuklayacak bir kuvvetinin olmadığı belirtilerek bu gençlerin İstanbul'dan Ayıntab'a kadar şu sırada seyahat edecek zekâda ve cesarette bulunduklarına göre tekrar darüleytamlarda yerleşmelerine gerek olmadığı ve kendi 
ekmeklerini kazanabilecekleri anlamına geldiği belirtilmiştir(MF. MKT, 1238/71). Bu bilgilerden Ayıntab darüleytamının 1918 yıında mülga olduğu anlaşılmaktadır.

\section{Ermenilere ait Darüleytamlar}

Yüzyıllarca birçok medeniyete ev sahipliği yapmış Ayıntab'a Ermenilerin yerleşmeye başlaması 16.-17. yüzyıllardan itibaren olmuştur. Zaman içerisinde gerek coğrafi konum gerekse ekonomik duruma paralel olarak yapılan göçlerle şehirdeki Ermeni nüfusta artmış ve XIX. yüzyıla gelindiğinde şehirdeki toplam nüfusun takriben 1/5 ini Ermeniler oluşturmuştur. Şehirde XIX. yüzyıl ortalarına kadar komşuluk ilişkileri çok iyi olan ve aynı mahallelerde yaşayan Müslüman halkla Ermeniler arasında ne ırksal ne de dini konuda sorun yaşanmamıştır. Fakat Osmanlı içinde bulunduğu durum ve emperyalist devletlerin Osmanlı üzerindeki politikaları vs. derken Türk-Ermeni ilişkilerini de olumsuz etkilemişti. Ancak Ayıntab'da 1895 e kadar iki millet arasında karşılıklı bir çatışma yaşanmamıştır(Güllü 2010:61,180; Çalışkan 2017:433). Şehirde Ermenilere ait birçok eğitim kurumu mevcuttu(A.Ş.S., 148/182,183; I.HR., Dos.No.170, Göm.No.9215; İ.HR., Dos.No.170, Göm.No.9215; MF.MKT. 14/38; HR.ID., 1597/9,10,11,12,13,14,15; Güllü 2010:101; Aytekin 2006:194). Ermeniler, Osmanlı hâkimiyet alanında XVIII. yüzyıl sonuna kadar geçen süreçte bir eğitim kurumuna sahip değildi. Ancak XIX. yüzyılda misyoner güçlerinde destek ve teşvikleriyle yalnızca Ayıntab da 40'a yakın okul açmışlardır(Vahapoğlu 1990:100). Bu okullar arasında yetimler mektebi olduğu da anlaşılmaktadır. 29 Kasım 1879 tarihinde Ayıntab'da yaşayan Protestan Ermenileri daha önce şehirde emsali olmadığı gerekçesiyle anasız ve babasız ortalıkta kalmış yetimlerin eğitimi amacıyla Hayıkbaba Mahallesinde üç katlı bir eytam mektebi açmak için ruhsat talebinde bulunmuşlardır(Y.PRK.UM, no.1/77). Protestan milleti için açılacak bu eytam mektebinin ruhsat izninin 19 Mart 1883 tarihinde verildiği anlaşılmaktadır(BOA. Y.A.RES. no. 19/32). Amerikan misyonerler öncülüğünde tüm Hristiyan yetimleri sahiplenecek olan Protestan cemaati adına açılacak bu okul fikrine Müslüman halkta destek vermiştir(Güllü 2010:95).

Araştırmacı yazar Barlas, Ermenilere ait Hayik Zimmiyan (Kayacık) Mahallesinde 1882 yılında bir eytamhane mektebi açıldığını ve sadece erkek yetimlerin okutulduğu bu okulun 1913 yılında kapatıldığını ifade etmektedir(Barlas 1971:54; Yıldıray 2010:106). Halep Vilayet Salnamelerinde ise 1321(1903-4) yılı itibariyle gayrimüslim okulları hakkında bilgi verilmeye başlanmıştır(Salnâme-i Vilâyet-i Haleb Sene 1321:233; 1322:238; 1323:251; 1324:239; 1326:234; Yıldıray 2010:106; Eroğlu, Babuçoğlu, Köçer 2007:63,571,572). Buna bilgilere dayanarak göre Ermeni eytamhanesi hakkında şu bilgiler yer almaktadır;

\begin{tabular}{llll}
\multicolumn{2}{l}{ Halep Salnamelerine Göre } & \multicolumn{2}{c}{ Uğurol Barlas'a Göre } \\
Tarih & Erkek & Tarih & Erkek \\
$1903-4$ & 25 & 1885 & 65
\end{tabular}




$\begin{array}{llll}1904-5 & 25 & 1890 & 65 \\ 1905-6 & 35 & 1900 & 32 \\ 1906-7 & 40 & 1905 & 26 \\ 1908-9 & 55 & 1907 & 35 \\ & & 1910 & 55 \\ & & 1912 & 50\end{array}$

1897 tarihinde Ermeni patrikhanesi tarafından, Dersaadet Ermeni Eytamhânesinde ve hayır sahiplerinin evlerinde bakılmak üzere Trabzon'dan 20, Malatya'dan 15, Bitlis'ten 5, Sis ve Diyarbakır'dan 25, Samsun'dan 10, Ayıntab'dan 5 ve Palu'dan 20, Bayburt'tan 25, Gürün'den 20, Van'dan 10, Urfa'dan 25, Ma'mûretü'laziz'den 40, Sivas'tan 20, Arabkir'den 35, Hısn-ı Mansur'dan 5, Çenguş'tan 10, Erzincan'dan 15 ve Kilis'ten 10 olmak üzere toplam 345 Ermeni yetimin İstanbul'a; bazı yetimlerin de Kudüs'e ve başka yerlerde bulunan yabancı okullara gönderilebilmeleri için izin istendiği anlaşılmaktadır(DH. TMIK. M, 38/59).

Ermeni yetimler okulu 1882-83 tarihlerinde açılmış ancak 1913 de kapanmıştır(Güllü 2010:96). 1920'den itibaren Türkiye'deki Ermeni yetimler yurt dışına çıkarılmaya başlanmıştır. İlk hareket Güneydoğu Anadolu'daki Türk, Fransız ve Ermeni çatışmaları sırasında güvenlikleri öne sürülerek başlamıştır. Özellikle Ayıntab'daki çatışmalar sırasında bölgeye toplanan 6000 yetim ve kadının 1920 Mayısı itibariyle Suriye'ye sevki başlamıştır(Atnur 2005:285; Çetinkaya 2009:118,119; Bakar 2005:586).

\section{Amerikalı ve İngiliz Misyonere ait Darüleytamlar}

XIX. yüzyılda siyasi gelişmelere paralel olarak emperyalist güçler Anadolu'da misyoner faaliyetlere girişmişlerdir. Bu bağlamda Fransızlar gibi Ermeniler üzerinde etkin rol oynayan devletlerden biride Amerika olmuştur. Amerika'nın misyonerlik faaliyetlerini yürütmek amacıyla 1810 tarihinde Boston da kısa adı ABCFM veya BOARD'ı(American Board of Commissioners for Foreign Missions) kurmuşlardır. Bu anlamda faaliyete geçtikleri şehirlerden biri de Ayıntab'dır. BOARD, birçok şehirde olduğu gibi Ayıntab'da da birçok okul, hastane, yetimhane açmışlardır(Çetinkaya 2009:72-76; Öztürk 2007:68). Her ne kadar misyonerlerin raporları doğrultusunda Ayıntab şehrinin 1848 tarihinde işgal edildiği ifade edilse de şehre gelerek keşfetmeleri 1818 yılına dayandırılmaktadır(Sevinç 2009:127; Barlas 2013:9). 1860'lara gelindiğinde 5 istasyon, 20 uç istasyon ile Merkezi Türkiye Misyonunun başkenti olan Ayıntab'da aynı zamanda 12 Protestan kilisesi, hastane, yetimhane ve 26 okulu vardı(Sevinç 2009:130; Öztürk 2019:18).

BOARD, hedefleri doğrultusunda faaliyete geçirdiği hastane, tıp fakültesi ve okullara ek olarak yetimhaneler açmıştır. Osmanlı Devleti, gayrimüslimlerin özellikle eğitim anlamında giriştikleri faaliyetleri sıkı denetim altında tutmaktaydı. Bu anlamda 1898 yılında Ayıntab'da Amerikalılar tarafından bir okul açıldığının duyulduğu, bu doğru ise ruhsatının hangi tarihte ve kim tarafından verildiğinin araştırılarak bildirilmesi istenmiş ve Ayıntab'da kaç Amerikan okulu olduğu, bunlardan kaçının ruhsatı ve 
kaçının ise ruhsatsız olduğu ve açılış tarihlerinin bildirilmesi hakkında Maarif Nezareti tarafından Halep Maarif Müdürlüğünden bilgi istenmiştir. Ayrıca yine Amerikalıların Ayıntab merkezinde ve şehrin güney kesiminde mektep şeklinde eğitim verilecek bir eytamhane açmak istedikleri ve Maarif Nezaretinden izin alınmadıkça bu okula kesinlikle ruhsat verilmemesi gerektiği belirtilmiştir. Yetimhanelerde sadece yetim çocukların kalabileceği, onların bütün bakımlarının burada yapılması gerektiği bunun ise hükümetin üzerinde bir vazife olduğu ve her türlü durumun mutlaka Dâhiliye Nezaretine bildirilmesi gerektiği ifade edilmiştir(MF. MKT, 380/46).

İlk olarak yetimler yönelik okul açmak için BOARD üyesi İngiliz madam Frison görevlendirilmişti. Bayan Frearson(Frison), mülkiyeti Amerikalı Mr. Martin'e ait olan ve adından dolayı halkın Martin(Mardin) Tepe dediği yerde 120 çocuğun barındığı yetimler evi açmıştır(1894-95). Barlas, Gaziantep Tıp Fakültesi Tarihi ve Azınlık Okulları eserinin bir sayfasında bu yetim evinin 1894 tarihindeki mevdunu 73 kız çocuk, 13 erkek çocuk olmak üzere toplam 86 olarak olarak verirken başka bir sayfada aynı tarihteki yetim mevcudunu aşağıda tablodaki gibi 57 erkek $62 \mathrm{kız}$ toplam 119 olarak vermektedir. Bu yetimhanelerde erkek çocuklar halı ve kilim işi, kız çocuklar ise Ayıntab işi, dantel yapıyorlar ayrıca ev işleri ve temizliğini yapıyorlardı. Yetim sayısı ise 1898 tarihinde Mardin Tepesinde 65; 1911 tarihinde erkek çocuklar evinde 129; Mardin tepesinde $133 \mathrm{kIz}$ ve 24 erkekti. Yirmi beş sene boyunca faaliyet gösteren bu kurum Ingiliz ve Amerikalıların yardımlarıyla ayakta kalmış ve daha sonra boşaltılarak Fransızlar tarafından işgal edilmiştir(1920)(MV, 233/42; Abadi 1959:13; Sevinç 2009:134; Barlas 1971:49,51; Maksudyan 2008:410).

Mardin Tepesindeki Protestan mektebi yani Amerikan yetim okulu, anaokulu ve ilkokul olarak iki kısımdan oluşmaktaydı(Yıldıray 2010:103). Şişman, eserinde Amerikalılara ait Protestan cemaati adına açılan yetimhanenin ruhsatname tarihini 8 Teşrin-i evvel 1318(Ekim 1902) olarak vermektedir(Şişman 2006:385). Bu yetimhanenin Mardin tepede bulunan yetimhane olması kuvvetle muhtemeldir. $\mathrm{Bu}$ anlamda yetimhanenin açıldığı tarihten çok sonra ruhsat almış olduğunu anlaşılmaktadır.

Okulun, salnamelerde ve Uğurol Barlas'ın eserinde yer alan bilgilere dayanarak bazı yıllardaki mevcuduna dair bilgiler şu şekildedir(Salnâme-i Vilâyet-i Haleb Sene 1321:233; 1322:238; 1323:251; 1324:239; 1326:234; Yıldıray 2010:103,106; Eroğlu, Babuçoğlu, Köçer 2007:63, 571, 572; Barlas 1971:47,48);

\begin{tabular}{|c|c|c|c|}
\hline $\begin{array}{ll}\text { Halep Salnamelerine } \\
\text { Göre }\end{array}$ & & Göre $\quad$ Uğurol Barlas'a & \\
\hline Tarih & $\begin{array}{l}\text { Erkek- } \\
\text { Kız }\end{array}$ & Tarih & Erkek-Kız \\
\hline 1903-4 & $37-59$ & 1894 & $57-62$ \\
\hline 1904-5 & $37-59$ & 1900 & $73-76$ \\
\hline $1905-6$ & $43-68$ & 1905 & $37-59$ \\
\hline $1906-7$ & $43-68$ & 1907 & $43-67$ \\
\hline
\end{tabular}




\begin{tabular}{|c|c|c|c|}
\hline $1907-8$ & $45-73$ & 1910 & $45-73$ \\
\hline & & 1912 & $72-44$ \\
\hline & & 1916 & $75-48$ \\
\hline
\end{tabular}

1900 tarihinde Amerikalıların Ayıntab'da bulunan yetimhanelerinde barınan toplam çocuk sayısı 132 idi(Kocabaşoğlu 2000:117). 1919 tarihine gelindiğinde Amerikalılara ait yetimhane sayısının 7'ye çıktığı anlaşılmaktadır(Abadi 1959:15; Sevinç 2009:134; Barlas 1971:32). Bunlar;

-Ms. Harris tarafından kurulan erkek çocuk yetimhanesi(mevcut 400)

-Ms. Forman “ k kız yetimhanesi(350 yataklı)

-M. Trovis “ erkek çocuk öksüz yurdu(mevcut 400)

-Ms. Bigili “ kadın ve çocuk yurdu(260 yataklı)

-Ms. Kelli(ni) “ k kadın ve çocuklar için kurduğu Şefkat

Yuvası(bez ve dantel dokuma işi yapan 1000 kadın barınmaktaydı.

-Genç Hristiyanlar Cemiyeti

Yetimhanelerin kuruluş amacına uygun olarak daha önce belirttiği üzere yetimlerin eğitimleri dâhilinde hem zanaat öğrenmeleri hem de kurumun işleyişi çerçevesinde gelir elde edilmesi amacıyla atölyelerde iş yapılıp satılıyordu. Ayıntab'da bulunan yetimhane atölyesinde çoğunluğu yetimhanede barınan çocuklar olmak üzere 250 kişi Ayıntab'a özgü iğne ve tığ işleri yapıyordu. Bu faaliyetler bir Amerikalı ve bir yerli halk çalışanı tarafından denetlenmekteydi(Kocabaşoğlu 2000:117; Güllü 2010:123). 1321(1904) tarihli bir arşiv belgesinden Ayıntab'da Amerikan misyonerlerine ait eytam mektebi haricinde eytamhane sanayi mektebi olduğu da anlaşılmaktadır ${ }^{\dagger}$. Amerikan misyonu doğrultusunda Urfa, Ayıntab ve Maraş'ta çalışan Ermeni kadın ve çocukları, İngiliz ve Amerikalı alıcılar için nakış işleri yapıyorlardı. 1911 senesinde şehirde İrlandalı bir firmanın temsilcisi tarafından yüzlerce kadın ve yetim kız istihdam edilmiştir. Burada yapılan keten mendiller ve danteller yakın küçük yerli firmalarla doğrudan Amerika Birleşik Devletleri'ne ihraç edilmiştir(Maksudyan 2008:326).

Amerikan misyonerlerine ait Urfa, Ayıntab, Maraş, Mardin ve civarlarında bulunan eytamhane atölyelerinde kurumda çalışan yetimler dışında intiyaç sahibi dul kadınlara çalışma imkânı verilerek el işleri öğretilmekte idi. Bu atölyelerde hammadde

†29 Şevvâl sene [1]323 tarihli tezkireye zeyldir. Ayntab'da Amerika Misyonerleri re'îsinin imzâsını hâvi olup İskenderun Amerika Konsolos tarafından musaddıkan ibrâz olunan bir kıt'a beyannâmede Eytam Mektebi'yle Eytamhâne Sanayi Mektebi'ne mahsus olduğu muharrer altı sandık mendil ve kazıcı ve elvan-ı harîr vesâire ile bıçkı ve rende makinesinden mendil ve kazıcı ve elvân-ı harîrin mu'âmele-i lâzımesi bi'l-icrâ Eytamhâne Müdüriyetine mahsûben imrâr etdirilmiş ise de mütebâki dört sandıkda iki bin dokuz yüz yetmiş beş kilo sıkletinde ma'a edevât-ı ahen bıçkı ve rende makinesinin o sûretle imrârında tereddüd olunarak gümrük resmi depozito sûretiyle bi'l-ahz imrâr etdirilmiş olduğu İskenderun Rüsumat Nezâreti'nden bildirildiğinden bahsile...BEO, 2758/206842_1; BEO, 2774/208028_1; BEO, 2774/208028_2; BEO, 2774/208028_3; DH. ŞFR, 47/409 
vs olarak kullanılan mendillik keten, tire makaralar, kazıcı, renkli ipekler, bıçkı ve rende makinesi gibi malzemeler yurtdışından(İngiltere gibi) deniz yoluyla İskenderun limanına getirtiliyor ve bu malzemelerden gümrük ücreti alınmıyordu(1328/1912)( BEO, 2774/208028-2; BOA.DH.ID.NR.59/57).

Amerikalılar 1916 yılı itibariyle bilhassa kadın ve çocuklar üzerindeki misyoner yardım çalışmalarını arttırarak Amerikan kamuoyunda da büyük bir propaganda çalışmasına girişmişlerdir. Amaçları doğrultusunda ciddi meblağlara ulaşan paralar öce İstanbul'a sonrada farklı yerlerdeki misyonerlere ve konsoloslara gönderiliyordu. En fazla harcamaların yapıldığı yerlerin başında Ayıntab'ın da bağlı olduğu Halep vilayeti geliyordu. Bu bağlamda Halep'teki yetimler için aylık Türk parası ile 1500 lira harcanırken Ayıntab da bulunan 400 kadın ve yetim çocuk için aylık masraf ise 1000 lira idi 2005:89). 1920 yılına gelindiğinde Ayıntab'da Amerikan himayesindeki Ermeni kadın ve çocuk sayısı 6000 idi. Şehirde Ermeni yetimlerin barındığı en büyük yetimhanelerden birinin Şekerciyan olduğu ifade edilmektedir. Ayıntab'da Türk-Fransız çatışmaları Amerikalıların faaliyetlerini de olumsuz etkilemiş tarafsız görünmeleri de işe yaramamış saldırılarda yetimhanede birkaç kişi ölünce Bayan Frearson(Frison) yetimhaneyi boşaltmak mecburiyetinde kaldığı ifade edilse de aslında Ermeni yetimhanesi içerisinde Türklere karşı Ermenilerin silahlandırıldığı gerçeği vardır(Atnur 2005:252,253). Durumun şehirde kötüleşmesi üzerine Nisan 1920 itibariyle Amerikalılara ait olan bu kurumların tamamı kapatılmış ve var olan kız-erkek tüm çocuklar Kızılhaç tarafından Amerika'ya gönderilmiştir(Barlas 1971:32,33).

Şehirde Amerikan misyonere ait yetimhaneler dışında İngiliz misyonerlere ait bir yetimhane olduğu anlaşılmaktadır. 1915 yılına ait bir belgede bu yetimhanede yalnızca kızların(inas) barındığı ve başında bir bayan müdire olduğu yer almaktadır(DH. EUM. 5. Şb, 15/4_2; DH. EUM. 5. Şb, 15/4_3; DH. EUM. 5. Şb, 15/4_4; DH. EUM. 5. Şb, 15/4_1).

\section{Sonuç}

Osmanlı Devleti için son dönem özellikle Balkan Savaşları ve Birinci Dünya Savaşı büyük yıkım olmuştur. Savaşların acı yüzü yapılma zorunda kalınan göçler ve göçmeler ayrıca geride kalan yetimler Osmanlı devletini yıpratan diğer konular olmuştur. Sosyal bir devlet olan Osmanlı hem kendinden önceki Türk devletlerinden devraldığı vakıf sistemini geliştirerek hem de yeni sosyal kurumlar meydana getirerek yetimlerine sonuna kadar kucak açmıştır. Bu anlamda açılan Darüleytamlar yani yetim evleri ülke çapında yayılmış, yetimlerin ve intiyaç sahiplerinin barınması, eğitilmesi, zanaat öğrenmesi amacıyla faaliyet göstermiş önemli bir kurumdur. Süreç içerisinde savaşların ortaya çıkardı ağır ekonomik sıkıntılar doğal olarak Darüleytamların işleyişini de zora sokmuştur. Bunun neticesinde darüleytamlar kapatılmaya başlanmıştır. Özellikle taşra darüleytamlarının tasfiyesiyle bir kısım yetim aile ve akrabalarının yanına yerleştirilirken bir kısmı da merkezde yani İstanbul darüleytamına yerleştirilmiştir. 
Vefakâr Ayıntab halkı her daim yetimlerine sahip çıkmış, Müslim-gayrimüslim ayırt etmemiştir. $\mathrm{Bu}$ anlamda gayrimüslim yetimhanelerinin açılmasını desteklemişlerdir. Ancak zaman içerisinde özellikle Amerikalı misyonerlerin Ayıntab'da yaşayan Ermeniler üzerindeki emelleri neticesinde Müslümanları geride bırakacak sayıda birçok yetimhane ve okul açmışlardır. XX. yüzyıl başlarında Müslümanlara ait tespit edilen iki yetimhane varken Amerikan misyonerlerine ait yedi ve bu misyonerlerin destekleriyle açılan Ermenilere ait bir yetimhane vardı. Nüfusunun büyük çoğunluğu Müslüman olan Ayıntab halkı kendi yetimlerine ve intiyaç sahiplerine sahip çıkacak yeterli yetimhane olmamasını üzüntüyle karşılamış ve yetimlerine sahip çıkacak çözüm arayışlarına girişmiş bu anlamda cemiyet kurma yoluna gitmişlerdir. Bu amaçla 1911 tarihinde yoksul ve çaresiz yetimlerin her türlü intiyaçlarının karşılanması ve eğitimleri için şehirde Ayıntab Himâye-i Eytam Cem‘iyyet-i İslâmiyesi(Müslüman Yetimlerini Koruma Cemiyeti) unvanıyla bir cemiyet bile kurmuştur.

\section{KAYNAKLAR}

\section{Ayıntab Şer'iyye Sicilleri(A.Ş.S.)}

Nr. $144,145,146,147,148$

\section{Vilayet Salnameleri}

Sâlnâme-i Vilayet-i Halep Sene-i 1290

Sâlnâme-i Vilayet-i Halep Sene-i 1302

Sâlnâme-i Vilayet-i Halep Sene-i 1308

Sâlnâme-i Vilayet-i Halep Sene-i 1321

Sâlnâme-i Vilayet-i Halep Sene-i 1322

Sâlnâme-i Vilayet-i Halep Sene-i 1323

Sâlnâme-i Vilayet-i Halep Sene-i 1324

Sâlnâme-i Vilayet-i Halep Sene-i 1326

\section{Başbakanlık Osmanlı Arşivi}

BOA. MF.MKT Nr. 1225/21, 1227/16, 1227/45, 1227/31, 1226/20, 1227/67, 1227/69, $1227 / 99,380 / 46,1227 / 20,1225 / 21,1226 / 104,1236 / 45,1238 / 71,14 / 38$

BOA. DH. TMIK. M. Nr. 38/59

BOA. MF. İBT. Nr. 559/44

BOA. MF-EYT. Nr. 3/81; 7/53

BOA. BEO. Nr. 2758/206842_1; 2774/208028_1; 2774/208028_2; 2774/208028_3 
BOA. MV. Nr. $233 / 42$

BOA. DH.iD.Nr. 59/57; 126/20

BOA. DH. EUM. Nr. 5. Şb, 15/4_2; 5. Şb, 15/4_3; 5. Şb, 15/4_4; 5. Şb, 15/4_1

BOA. DH. EUM. EMN. Nr. 103/22

BOA. DH. HMŞ. Nr. 3-1/8-2

BOA. DH. İ. UM. EK. Nr. 28/104

BOA. DH. ŞFR. Nr. 47/409

BOA. İ.HR. Nr.170/9215

BOA. Y.A.RES. Nr. 19/32

BOA. HR.íD. Nr. 1597/9, 10, 11, 12, 13, 14, 15

BOA. Y.PRK.UM. Nr. 1/77

KITTAP VE MAKALELER

ABADI, (1959), Türk Verdünü Gaziantep,Antep'in Dört Muhasarası, Gaziantep: Mürüvvet Matbaası.

AKYÜZ, Yahya, (1999), Osmanlı son döneminde kızların eğitimi ve öğretmen Faika Ünlüer'in Yetişmesi ve Meslek Hayatı, Milli Eğitim Dergisi, S.143: s. 12-32.

ATEŞ, İbrahim, (1982), "Hayrı ve Sosyal Hizmetler Açısından Vakıflar", Vakıflar Dergisi, S.15, s. 55-88.

ATNUR, İbrahim Ethem, (2005), Türkiye'de Ermeni Kadınları ve Çocukları Meselesi (1915-1923), Ankara: Babil Yayıncılık.

AYHAN, Halis - MAViş, Hakkı,(1994), "Dârüşşafaka", Diyanet İslam Ansiklopedisi, Türkiye Diyanet Vakfı Yayınları, C.9, s. 7-9, İstanbul.

AYTEKIN, Hakan, (2006), 1914-1924 Yılları Arasında Korunmaya Muhtaç Çocuklar ve Eğitimleri, Yayımlanmamış Yüksek Lisans Tezi, Marmara üniversitesi Türkiyat Araştırmaları Enstitüsü, İstanbul.

AYTEKIN, Halil, (1999), "Antep'te Eğitim Kurumları(19. Yüzyılın İlk Yarısından 20. Yüzyılın İlk Yarısına Kadar)", Cumhuriyetin 75. Yılına Armağan Gaziantep, Ed. Yusuf Küçükdağ, Gaziantep, s.187-206.

BARLAS, Uğurol, (1971), Gaziantep Tıp Fakültesi Tarihi ve Azınlık Okulları, Gaziantep: Gaziantep Kültür Derneği Yayınları.

BARLAS, Uğurol, (1960), “Gaziantep Belediyesi Tarihi”, Gaziantep Kültür Dergisi, S.30: s. 11-23. 
BARLAS, Uğurol, (2013), 19. Ve 20. Yüzyıl Gaziantep Tıp Tarihi, İstanbul: Hilmi Barlas Eğitim Vakfı.

BAKAR, Bülent, (2005), "Mondros Mütarekesi'nden Sonra Yaşanan Önemli Bir Problem: Türk Ve Ermeni Yetimleri Sorunu", Atatürk Araştırma Merkezi Dergisi, C.XXI, S.62: s.569-588.

ÇALIŞKAN, Adem, "159 Numaralı Şer'iyye Sicili'ne Göre Ayntab Ermenileri'nin SosyoEkonomik Hayatları”, Bozkırdan Batıya: Prof. Dr. Hüseyin Salman’a Armağan, (Ed. Güler Yazıcı), İstanbul: Epsilon Yayınevi, 428-452.

ÇANLI, Mehmet, (2002), “Eytam İdaresi ve Sandıklar (1851-1926)", Türkler, Ankara: Yeni Türkiye Yayınları, s. 57-73.

ÇETINKAYA, Selma, (2009), 1915- 1923 yılları arasında Türkiye'deki Ermeni Yetimleri, Yayınlanmamış Yüksek Lisans Tezi, Erciyes Üniversitesi Sosyal Bilimler Enstitüsü, Kayseri.

DOĞAN, Ayhan, (2014), "Osmanlı Devleti'nde Alman Kültürel Yayılmacılığı: Maraş Örneği”, Gaziantep University Journal of Social Sciences, C. II, S. 13, s.437-462.

DÖNMEZ, İbrahim Kâfi, (1986), "Yetim”, İslam Ansiklopedisi, İstanbul: Milli Eğitim Basımevi, s. 401-403.

DíKicl, Esra, (2019), Kur'ân'da Yetim Kavramı ve Osmanlı Devleti'nde Yetim Kurumları(Bir Kur'ân Kavramının Kurumsallaşması), Yayınlanmamış Yüksek Lisans Tezi, Karabük Üniversitesi Sosyal Bilimler Enstitüsü, Karabük.

ENÇ, Mazlum, (1962), “Antep’te Maarifi İslamiye Cemiyeti Ve Hizmetleri”, Gaziantep Kültür Dergisi, S.50: s. 5.

ERGIN, Osman, (1977), Türkiye Maarif Tarihi, C.III-IV, İstanbul: Eser Matbaası.

EROĞLU, Cengiz; BABUÇOĞLU, Murat; KÖÇER, Mehmet, (2007), Osmanlı Vilayet Salnamelerinde Halep, Ankara: Global Strateji Enstitüsü.

GÖĞÜŞ, Mehmet Oğuz, (t.y.), IIlk Insanlardan Bugüne Çeşitli yönleriyle Gaziantep, Gaziantep:Cihan Ofset.

GÜLLÜ, Ramazan Erhan, (2010), Antep Ermenileri(Sosyal-Siyasi ve Kültürel Hayatı), İstanbul: IQ Kültür Sanat Yayıncılık.

IŞERI, Murat, (2014), Osmanlı Çocuk Koruma Sistemi Ve Darüleytamlar (18511923), Yayınlanmamış Yüksek Lisan tezi, Kırıkkale Üniversitesi Sosyal Bilimler Enstitüsü, Kırıkkale.

INANÇ, Veli, (2002), Eytam İdaresi-Sandıkları ve Marmaris Örneği(1885-1911), Muğla Üniversitesi Sosyal Bilimler Enstitüsü, Yayınlanmamış Yüksek Lisans Tezi, Muğla.

KANAR, Mehmet, Osmanlı Sözlüğü, http://tarihvemedeniyet.org/2009/08/osmanli-turkcesi-sozlugu-mehmet kanar.html(18.02.2020). 
KAPCI, Hikmet Zeki, (2012), Yetimlere Yönelik Bir Eğitim Kurumu Darülhayr-i Âli, Erciyes Üniversitesi Sosyal Bilimler Enstitüsü, Kayseri.

KARATAŞ, Zeki, (2015), "Osmanlı Devleti'nde Korunmaya Muhtaç Çocuklara Yönelik Sosyal Hizmet Uygulamaları", Manevi Temelli Sosyal Hizmet Araştırmaları Dergisi, C.I, S.1: s. 16-31.

KOCABAŞOĞLU, Uygur, (2000), Anadolu'daki Amerika, Kendi Belgeleriyle 19. Yüzyılda Osmanlı İmparatorluğu'ndaki Amerikan Misyoner Okulları, Ankara: İmge Kitapevi.

KOÇ, Aylin(2003), Öksüz ve Yetim Çocuklar İçin Kurulmuş Bir Eğitim Kurumu: Darüşşafaka, Savaş Çocukları Öksüzler ve Yetimler, ed.Emine Gürsoy-Naskali ve Aylin Koç, İstanbul: Umut Kağıtçılık, s.183-193.

MAKSUDYAN, Nazan, (2008), Hearıng The Volceless - Seeıng The Invisıble: Orphans And Destitute Chıldren As Actors Of Social, Economic, And Polıtıcal Hıstory In The Late Ottoman Empıre, Sabancı Üniversitesi Sosyal Bilimler Enstitüsü, Yayınlanmamış Doktora Tezi, İstanbul.

MÜEZZiNOĞLU, Ersin, (2012), “I. Dünya Savaşı Esnasında Yetim ve Öksüz Çocukların Himayesi ve Eğitimi: Darüleytamlar", History Studies, Volume 4/1: s. 399417.

NAZIRII, Sonita, (2019), Kur'an-ו Kerim'de Yetimler, Yayınlanmamış Yüksek Lisans Tezi, Erciyes Üniversitesi Sosyal Bilimler Enstitüsü, Kayseri.

NUHOĞLU, Hidayet Yavuz, (1993a), "Dârülaceze", Diyanet İslam Ansiklopedisi, Türkiye Diyanet Vakfı Yayınları, C.VIII, İstanbul, s.512-514.

NUHOĞLU, Hidayet Yavuz, (1993b), "Dârüleytam", Diyanet İslam Ansiklopedisi, Türkiye Diyanet Vakfı Yayınları, C. VIII, İstanbul, s.521.

OKUR, Yasemin, (1996), Darüleytamlar, Yayınlanmamış Yüksek Lisans Tezi, Ondokuz Mayıs Üniversitesi Sosyal Bilimler Enstitüsü, Samsun.

ÖZKAN, Salih, (2006), "Türkiye'de Darüleytamların Gelisimi ve Nigde Darüleytamı", S.Ü.Türkiyat Arastırmaları Dergisi, C.II, S.19: s. 211-229.

ÖZTÜRK, Ayhan, (2007), "Amerikan Board'un Kuruluşu, Teşkilatlanması Ve Osmanlı Devleti'nde Kurduğu Misyonlar”, Sosyal Bilimler Enstitüsü Dergisi, S. 23/2: s. 63-74.

ÖZTÜRK, Cemil, (1999), "Islahhâne”, Diyanet İslam Ansiklopedisi, C. XIX, s.190191, İstanbul: Türkiye Diyanet Vakfı Yayınları.

ÖZTÜRK, Erdem, (2019), Amerikan Board Misyoner Yapısı Şanlıurfa Ermeni Yetimhanesi Koruma Sorunları Ve Çözüm Önerileri, Yayımlanmamış Yüksek Lisans Tezi, Yıldız Teknik Üniversitesi Fen Bilimleri Enstitüsü, İstanbul.

PAKALIN, Mehmet Zeki, (1993), Tarih Deyimleri Ve Terimleri Sözlüğü, C.I, İstanbul: MEB Yayınları.

ŞAHIN, Furkan, (2017), Eytam Sandıklarının Kuruluşu ve Konuyla İlgili Yapılan Yasal Düzenlemeler, Ankara Üniversitesi Sosyal Bilimler Enstitüsü, Yayınlanmamış Yüksek Lisans Tezi, Ankara. 
ŞAFAK, Nurdan, (2013), "Dârüleytamda Çocuk Olmak: On Çocuk On Portre", FSM İlmî Araştırmalar Insan ve Toplum Bilimleri Dergisi, S. 2, Güz/Autumn, s. 261-283.

SAMi, Şemseddin, (1317), Kamus-ı Türki, Dersaadet: İkdam Matbaası.

SEVINÇ, Necdet, (2009), Osmanlı'dan Günümüze Misyoner Faaliyetleri Okullar, Kiliseler, Yardım Kuruluşları, İstanbul: Bilgeoğuz Yayınları.

ŞişMAN, Adnan, (2006), XX. yüzyıl Başlarında Osmanlı Devletinde Yabancı Devletlerin Kültürel Ve Sosyal Müesseseleri, Atatürk Araştırma Merkezi, Ankara.

VAHAPOĞLU, M. Hidayet, (1990), "Osmanlı'dan Günümüze Azınlık ve Yabancı Okulları(Yönetim Açısından)", Türk Kültürünü Araştırma Enstitüsü, Seri:1, Sayı:A.20, Ankara, 1990, s.100

YAZICI, Nesimi, (2007), "Osmanlılarda Yetimlerin Korunması Üzerine Bazı Değerlendirmeler”, AÜIFD, XLVIII (2007), S. I, s. 1-46.

YAZICI, Nesimi, (1995), “Tanzimat Döneminde Yetim Mallarının Korunmasına Yönelik Yasal Düzenlemeler ve Bazı Uygulamalar”, Vakıf Haftası Dergisi, S.12: s.45-53.

YEDIYYILDIZ, Bahaeddin, (1999), "Osmanlılar Döneminde Türk Vakıfları ya da Türk Hayrât Sistemi”, Osmanlı, Ankara: Yeni Türkiye Yayınları.

YENER, Şakir Sabri, (t.y.), Gaziantebin Yakın Tarihinden Notlar (Gaziantep'lilerin Maarife Hizmetleri), Gaziantep: Gaziyurt Matbaası.

YILDIRAY, Yıldırım, (2010), Halep vilâyet salnâmelerine göre (1867-1908) Ayıntâb, Yayımlanmamış Yüksek Lisans Tezi, Gaziantep Üniversitesi Sosyal Bilimler Enstitüsü, Gaziantep. 